\title{
The Role of Internal Control in Raising Employee Productivity in Jordanian Bank
}

\author{
Zead M. Alhawamdeh and Mahmoud M. Alhawamdeh
}

\begin{abstract}
Internal control helps organizations achieve their objectives and maintain and improve their performance, and the performance of their employees. The Committee of Sponsoring Organizations of the Tread Way Commission issued an Internal Control - Integrated Framework, to help organizations in designing, implementing, and conducting internal control and assessing their internal control systems' effectiveness, this Integrated Framework, included the five factors of control system, which are Control Environment, Risk Assessment, Control Activities, Information and Communication, and Monitoring Activities. The research examines the relationship between internal control system of an organization and employee engagement, and the effect that such has on the performance of the employee in the organization, and job satisfaction. This research primarily aims at finding out the impact of internal control system on employee performance in Jordanian companies, especially those in the Jordanian banking sector. Internal control systems will influence employees' performance in two ways, through having an effective internal control system, or through not having an effective internal control system. The research therefore tends to evaluate the extent of adherence to internal control System in Jordanian banks, its impact on the performance of employees, and finally the recommendations of the researcher.
\end{abstract}

Index Terms-Internal Control, Employee Engagement, Performance, Banks, Internal Audit, Jordan.

\section{INTRODUCTION}

Management scholars have been interested in studying many administrative issues and problems, in order to raise productivity of the organizations in various activities. Management is an activity directed towards effective cooperation and coordination among different human efforts in order to achieve a particular objective with a high degree of competence (Nemer et al., 1996).

Every goal that wants to be achieved, a plan will be drawn up to clarify the producers, methods of work, programs and policies that will be pursued to achieve that goal. And to let plan to be implemented, this requires monitoring of administrative processes to ensure that the work is proceeding according to the plan.

Supervision is one of the most important administrative functions, because of the methods and procedures that used to evaluate the achievements required.

Administrative control over the work of public sector is necessary to eliminate many mistakes that hinder the achievement interests of citizens; the process of monitoring

Published on August 10, 2019.

Z. M. Alhawamdeh is with the Faculty of Economics and Administrative Sciences, Jerash University, Jordan.

Mahmoud M. Alhawamdeh is with the Girne American University. is not limited to ensuring the proper conduct of performance, but also ensuring that the best services are provided on time and at the required speed. (Alhabebe, 1990).

The system of supervision in question may not achieve its goal unless it is accepted by the staff and worked to apply it in the proper manner.

This research will define internal control, the components of internal control, employee engagement, Employee engagement and productivity, internal auditing in banks, and finally will discuss the implementation of internal control system in Jordanian banks.

\section{Aim OF StUdY}

The main aim of this research is to explore the extent by which Jordanian companies apply internal control systems within their organizations, and the extent that applying such contributes to making employees more productive and more efficient in the work they do., especially within the banking sector and understand how banks are applying internal control systems to increase engagement and performance of its employees.

\section{OBJECTIVES OF STUDY}

* Designing a process that is reliable and effective for data collection using the interview method, in a way that this process abides by ethical standards.

* To distinguish between organizations that are applying an effective internal control system than from those which are not applying an effective internal control system?

* To understand if there are external factors, such as economic, political and cultural that affect the way banks apply their internal control system.

* To investigate the factors that influence bankers to review their internal control systems frequently and on a continuous basis, and the elements they consider in evaluating whether their system is effective in making employees engaged or not.

\section{RESEARCh Problem:}

* Most of the Jordanian companies have some weakness in internal control, that's because using the wrong control means and bias in decisionmaking, this leads to reducing job satisfaction which directly effects on productivity and reduces financial performance. 


\section{RESEARCH QUESTIONS}

* What are the most important requirements for effective management control to raise staff performance?

* What is the relationship between the supervisory methods and the level of performance efficiency of employees?

* What are the difficulties faced by internal observers?

\section{Methodology AND Data ANAlysis}

There are three different perspectives Research philosophies, first, the positivistic approach (Pugh, Hickson and Hinings, 1969), seond, the social constructionism (Berger and Luckmann, 1966; Cunliffe, 2008) and third, the critical realism (Bhaskar, 1978). This research will be based on a critical realism philosophical approach (Bhaskar, 1978) this is because the researcher would like to get rich qualitative data, and acquire deep understanding of how Jordanian banks are applying internal control systems within their organizations.

The method for collecting data will include two parts, the first part will be the collection of data and second part will be the processing of the data collected, the research will be conducted using face-to-face interviews with board of directors and managers, and employees will be given questionnaires to recognize their thoughts and opinions regarding internal control systems and its effectiveness in making them more engaged in their jobs, and both methods of research will help in exploring whether there are external factors, such as the economic, political and cultural factors, that influence the application of internal systems in banks.

The questions of the interview will be both structured and semi-structured questions, this combination will help acquire better understanding of participants' thoughts and opinions, as suggested by Spradley (1979).

\section{BACKGROUND OF STUDY: INTERNAL CONTROL SYSTEMS IN BANKS}

Customers look for banks that can manage risks in an effective way; therefore, banks usually ensure they have internal control systems that can manage risks in the most effective ways. If for example a bank does not have an effective internal control system, this bank would be seen as vulnerable (Länsiluoto et al, 2016). Nowadays internal control is linked mainly to risk management; it is for this reason that internal control should cover the identification and justification of risks since internal controls are seen these days to help assist the organization in managing its risks and promoting effective process of governance (Spira and page, 2003).

Banks should satisfy customers rather than control them, customer feedback is a way through which banks can make sure that their customers are satisfied, in order for banks to reach customer satisfaction, banks should first make sure that their employees are satisfied in their jobs by finding joy while they work (Senaweera, 2008). Effective lines of communication with employees regarding to compliance worries, inquiries, or complaints, and training of employees on the organization's objectives and policies are important aspects of internal control systems according to Williford and Small (2013). Such enhances the organization's performance and increases its value besides its reputation.

An essential matter in the implementation process is to have the support of department managers and the employees (ICDF, 2003), especially that the enforcement of internal control is made through people, system, and processes (Rasmussen, 2013). Internal Controls are more effective when they are part of the organization's culture and management promotes values of integrity and honesty to its employees, and assures them that appropriate and easily understood internal control procedures and processes are in place (Edwards and Wolfe, 2004).

\section{BACKGROUND OF PROBLEM: APPLICATION OF INTERNAL CONTROL SYSTEMS IN JORDANIAN BANKS}

Several studies were conducted about the application of internal control systems in the main Jordanian banks, such as, Al-Zoubi, et al. (2007), Al-Zubi, et al. (2014), Al-Jarrah (2012), and Bawaneh (2011).

Historically 10 years ago, and in the study conducted by Al-Zoubi, et al. (2007), managers and decision makers of Jordanian banks used to implement reactive approaches in response to the market and the instructions led down by specialized authorities at that time, The study done by Bawaneh (2011) revealed that the Jordan Banking Sector has been paying a lot of attention to corporate governance lately, and the results of Al-Jarrah (2012) stated that Jordanian banks in Jordan have been aware of risks, and undertook suitable actions to lessen risks, while the study conducted by Al-Zubi et al. (2014) found that a large number of respondents claimed that structures, reporting lines, and proper authorities and responsibilities were to achieve the bank's objectives, and the result of this study was that, an effective system of internal control requires an effective management, and employees being aware of the policies and procedures of the bank.

\section{Previous STUdY:}

There are existing studies that have shown a positive link between different kinds of employee engagement and business results. Mathew, Ogbonna, and Harris (2011) proved that profitability and growth in software companies can be a result of job satisfaction and performance at work, at the same time organization innovation could also be the result of the quality of work done by employees. According to the Gallup Organization only $20 \%$ of U.S. employees were disengaged, and an additional $54 \%$ were neutral about their work (Fleming et al., 2005). Gallup Inc. in 2010 also suggested the higher ratio of engaged employees guarantees superior financial performance in an organization. Regardless of the proof that employee engagement was important to business outcomes, few studies have studies and discussed the background of this matter, (Bakker, van 
Emmerik, \& Euwema, 2006). Harter, Schmidt, Killham, and Agrawal (2009), and Buckingham \&Coffman (1999) showed that employee engagement and business outcomes share a direct relationship. But there have been only a few studies on the subject of the relationship between internal controls and Employee Engagement and productivity.

Alsaeed, (2008) showed that there is a positive relationship between the performance of commercial banks', and the effectiveness of their internal control systems. Alsakkaf, (2007) found that Monitoring is an ongoing administrative task, mainly aimed at providing program managers and key stakeholders with regular comments and early indications of progress or lack of progress in achieving desired outcomes of the organization.

The internal control of any institution is the main pillar of the regulations, instructions and procedures established (Nemer et al., 1996).

\section{A. Internal Control System}

Different researchers have defined Interal Control Systems, for example Hamed (2009) points out that Interal Control Systems refer to the functions and procedures organised and established by management for the business to be successful. A more illustrative definition was that of Keitany, 2000); Internal Control System is all the means and techniques and procedures which are led down and implemented by management to achieve the best results in areas such as cooperation between management and employees, the protection of organization capital, the detection and prevention of fraud, in addition to the preparation all beneficial financial information. In the field of Financial Organizations such as banks, Whittington (2001) has defined Internal Control System as the procedures that are linked directly to matters of accounting and financial statements, and this system leads to the evaluation of the effectiveness of these procedures in achieving the objectives of the business itself.

\section{B. Components of Internal Control System}

In 1992, the Internal Control-Integrated Framework (Framework) was developed and published by the Committee of Sponsoring Organizations of the Treadway Commission (COSO) which is a model for assessing internal controls. Organizations across the world recognized this framework and adopted it to act as standards through which they measure the effectiveness of their own Internal Control Systems (COSO, 1999)

After the great recognition of the COSO Internal ControlIntegrated Framework (Framework) of 1992, a new 2013 Framework was published with the expectation to help organizations in designing and implementing Internal Control Systems in the new and changed environments in which businesses are operating these days, and helps them in deciding what makes good and effective internal control (COSO,2013)

According to the COSO Framework, Internal control consists of five integrated components, Control Environment, Risk Assessment, Control Activities, Information and Communication, Monitoring Activities, which will be explained next:

\section{Control Environment}

The control environment is the basis from which the organization implements internal control which consists of a number of standards, processes, and structures. Usually the board of directors and top management put down the rules that emphasis the importance of internal control and the desired conduct expected from employees of the organization (COSO, 2013).

\section{Risk Assessment}

Risk Assessment is the second component according the COSO framework (COSO, 2013); every organization faces a number of internal and external of risks. Risk could be defined as the possibility that an event will happen and such event will impact achieving the organization's objectives. Therefore, it is important to assess Risk, this is done through dynamic and iterative procedures that identify and assess various risks to achieving one's objectives. Risk assessment is important because it helps management determine how these risks will be managed, but Risk Assessment cannot be carried unless the organization has set out its objectives clearly (Frazier\& Spradling 1996).

\section{E. Control Activities}

Control activities include managements reviews; suitable activity controls for the different departments or divisions of the organization; physical controls; checking for compliance with limits and follow-ups regarding on non-compliance; a system of approvals and authorizations; and, a system of confirmation and settlement (Basle,1998).

\section{F. Information and Communication}

Any organization needs Information for it to be able to carry out its responsibilities to support the achievement of its objectives. It is the duty of management to obtain or produce and use relevant and quality information from both internal and external sources to maintain the best functioning of the other components of internal control. The process of providing, sharing and obtaining information is what is called Communication. Through internal communication information goes across the organization, which allows for employees to receive messages from management regarding control responsibilities and their importance.

\section{G. Monitoring Activities}

According to (Thornton, 2009) Monitoring activities should evaluate (1) whether management should reconsider the design of controls when risks change, and (2) whether the controls that have been planned to reduce risks continue to operate effectively, the monitoring process provides management with information about the internal control system at all times, this is because it assesses the processes and the results of these processes in achieving the objectives of the organization.

\section{H. Relationship between Internal control and Employee performance}

One of the main objectives of the internal control systems is efficiency and effectiveness of activities (performance objectives); this is where the organization seeks to ensure that the employees of the organization are doing their job to 
achieve the objectives and goals of the organization with honesty and integrity, with the least costs on the employer (Basle,1998), another link between internal control systems and employee performance is through the process of communication, a study done by (Mishra, Boynton \& Mirsha 2014) found that when employees are engaged using strong internal communications such as meetings, senior managers presentations, creating feedback mechanisms for employees, and finally creating methods to evaluate if such methods are effective or not in in making employees feel part of the organization and achieving its goals, employees become more productive and feel more fulfilled in their jobs.

\section{ETHiCAl CONSIDERATION}

This research will be grounded on the no harm to others principle as justified by Stening and Stubik (2007). The research will avoid deception, bias, and untruthfulness. Participants will be respected and the research will be conducted without causing the participants any harm, all data will be kept private and confidential, and only used only for the purpose of this research. Researcher will first obtain the Consent of the participants; participants will also be informed before the interview or before taking part in the questionnaire that they have the right to withdraw from participating at any time during the research.

Participants will also be given a hard copy of their rights in the research process, as well as informed verbally before the interview takes place. Recording will take place and participants will be informed such and their permission will be taken before starting the recording. The researcher will also inform participants regarding the purpose and aim of the research, and how the researcher will gather the data required for such, finally, Contact details of research supervisor will be provided in case the participant wanted to contact them

English is not the first language in Jordan, where the research will conducted, therefore the main ethical consideration is the language barrier, even though a large number of the population have a good level of English language knowledge, the researcher believes that participants will be able to express themselves better fluently in Arabic than in English, because making participants use English instead of Arabic in their answers, may cause the loss the richness of the information the participants are trying to give, and some things may be lost in translation .

However, translating interview questions into Arabic will enable the researcher to receive richer, profounder data. It may also allow the participants to understand each question more clearly, and respond accordingly, this will eventually lead to getting more accurate answers, more valid, and more reliable information form participants.

\section{RESEARCH LIMITATIONS/IMPLICATIONS}

Time restrains for gathering and analyzing data will be the main limitations of conducting a qualitative research; however, researcher hopes that rich data will be provided, because the thoughts and opinions of each participant would lead to better understanding of the matter investigated.

It may also be somewhat difficult to handle Interviews but this is largely dependent on participants, since some participants may respond with short answers leaving the researcher with limited or no information. Therefore, inquiry questions may be used when needed to help participants respond better, and therefore generate better quality information that could then be used more effectively in the data analysis.

Another Limitation of using a qualitative research method, is using an interview based research, this method could result in response bias, and reflexivity will can be avoided by using triangulation (Patton, 2002) which is looking at other documents and archival records, to triangulate the findings of this research to get more valid, and credible data. It must be noted though that triangulation requires a larger budget, and can be time-consuming, that is because the researcher is not only analyzing one set of data, but analyzing multiple methodologies. Many researchers fail to make obvious how triangulation has been achieved (Oberst, 1993).

\section{REFERENCES}

Al-Jarrah, I. (2012). "Evaluating the riskiness of the banking sector of Jordan", European Journal of Economics, Finance and Administrative Sciences.No.48, pp.87-94.

Al-Zoubi, K., Atier, M. (2007). "Jordanian Banks Compliance with Basel II \& the Effect on Banks' Capital Risk", pp 1-34.

Al-Zubi, Z., Shaban, O. and Hamdallah, M. (2014). "The Extent of Employee's Compliance to the Internal Control System on the Reliability and Creditability of Financial Statements", Journal of Scientific Research \& Report, No.5, pp. 940-950.

Althakafi, A. (1994). "The impact of multiple control on government agencies". King Abdulaziz University, Faculty of Economics and Administration, Kingdom of Saudi Arabia.

Alhabebe A. (1990) "General Administration”, Cairo, Ain Shams Library. p229, 231

Alsaeed, M. (2008), "The role of internal control in promoting performance in commercial banks", Sudan University of Science and Technology, College of Graduate Studies.

Alsakkaf, H. (2007) "Administrative control and its relationship to efficiency of performance", Republic of Yemen, Ministry of Public Health and Population.

Bakker, A.B., Van Emmerik, H., \& Euwema, M.C., 2006." Crossover of burnout and engagement in work teams". Work and Occupations, 33: 464-489.

Basle. (1998) "FRAMEWORK FOR INTERNAL CONTROL SYSTEMS IN BANKING ORGANISATIONS" Basle Committee on Banking Supervision, accessed 4/5/2017:http://www.bis.org/publ/bcbs40.pdf

Bawaneh, S. (2011). "The Effects of Corporate Governance Requirements on Jordan Banking Sector", International Journal of Business and Social Science, Vol. 2, No. 9, pp 130.

BCBS. (2012) "The internal audit function in banks", Available at: http://www.bis.org/publ/bcbs223.pdf Accessed online 8/5/2017

Berger, P. L. and Luckmann, T. (1966) The Social Construction of Reality: A Treatise in the Sociology of Knowledge. New York: Anchor Books, Doubleday

Buckingham, M., \& Coffman, C. (1999). "First, break all the rules: What the world's greatest managers do differently". New York, NY.: Simon \& Schuster.

COSO (1999)," Internal Control Integrated Framework", The Committed Sponsoring Organization (COSO) of The National Commission of Fraudulent Financial Reporting the (Treadway Commission).

COSO (2013), "Internal Control Integrated Framework, Executive Summary", the Committed Sponsoring Organization (COSO) of the National Commission of Fraudulent Financial Reporting the (Treadway Commission).

Cunliffe, A. L. (2008) Orientations to Social Constructionism: Relationally Responsive Social Constructionism and its Implications for 
Knowledge and Learning. Management Learning, Vol. 39, No. 2 , p.123-139.

Edwards, J. and Wolfe, S. (2004). "The compliance function in banks", Journal of Financial Regulation and Compliance, Vol. 12 No. 3, pp. 216-224

Fleming, J.H., Coffman, C. \& Harter, J.K. (2005). "Manage your human sigma". Harvard Business Review. Vol 83, No 7. Pp 106-14.

Fraizer D.R. \& Spradling L.S. (1996), "The New SAS" No:78.,CPA Journal, 66(5)

Gill, Preetinder Singh, "An Investigation of Employee Engagement and Business Outcomes at an Engineering Services Firm" (2012). Master's Theses and Doctoral Dissertations. Paper 452.

Hamed, A. (2009). "A clear Look at Internal Control: Theory and Concept". Unpublished MBA Research Paper. University of Nairobi

Harter, F. L., Schmidt, T. L., \& Hayes. (2002)." Business-unit-level relationship between employee satisfaction, employee engagement, and business outcomes: A meta-analysis". Journal of Applied Psychology, 87 (2002), pp. 268-279

Harter, F.L., Schmidt, E.A. Killham, and Agrawal, S. (2009) "Q12 MetaAnalysis: The Relationship between Engagement at Work and Organizational Outcomes," Gallup, http://www.aamga.org/files/hr/MetaAnalysis_Q12_WhitePaper_2009. pdf

ICDF, International Cooperation and Development Fund, (2003). "The Establishment of an Internal Control system". Available online at https://www.icdf.org.tw/web pub/20040517151210The\%20Establish ment.pdf.

JKB, (2014)," 2014 Annual Report Jordan Kuwait Bank" Available online at: $\quad$ http://www.jkb.com/sites/default/files/JKBAnnualReport_\%20English_2014.pdf. Accessed 7/5/2017

Kahn, W.A. (1990).” Psychological conditions of personal engagement and disengagement at work". Academy of Management Journal, 33, 692724.

Keitany, J. L. (2000). "The Internal Audit Control Function and its Implication for Risk Assessment by the External Auditor: A Case of Quoted Companies". Unpublished MBA Project Report, School of Business, University of Nairobi.

Länsiluoto, A., Jokipii, A. and Eklund, T. (2016). "Internal control effectiveness-a clustering approach", Managerial Auditing Journal, Vol. 31, No. 1, pp. 5-34.

Lydia L.F., Schleifer. M, Greenawalt, B. (1996) "The internal auditor and the critical thinking process", Managerial Auditing Journal, Vol. 11 Issue: 5, pp.5-13, doi: 10.1108/02686909610120479

Lord, S. (2013) “An Overview of COSO’s 2013 Internal Control-Integrated Framework" accessed online 4/5/2017: http://rsmus.com/pdf/wp_coso_2013 internal_control integrated fra mework.pdf

Mathew, J., Ogbonna, E., \& Harris, L. C. (2011). "Culture, employee work outcomes and Performance: An empirical analysis of Indian software firms". Journal of World Business.

May, D.R. Gilson, R.L. and Harter, L.M. (2004) "The psychological conditions of meaningfulness, safety and availability and the engagement of the human spirit at work", Journal of Occupational and Organisational Psychology, Vol 77, pp11-37

Mishra, K., Boynton, L., \& Mishra, A. (2014). Driving employee engagement: The expanded role of internal communications. Journal of Business Communication, 51(2), 183-202.

Nemer et al., (1996 ), "General Administration, Foundations and jobs", Riyadh, Al Farazdeq Printing Press.

OBERST, M. T. 1993. Possibilities and pitfalls in triangulation. Research in Nursing and Health, vol.16(6), pp.393-394.

Pugh,D.S.,Hickson,D.J.,\&Hinings,C.R.(1969a).Anempiricaltaxonomyofstr uctures of work organizations. Administrative Science Quarterly, 14, $115-126$

Ramussen, M. (2013). "Compliance efficiency in an integrated GRC platform", GRC 20/20 research. Available online at: http://grc2020.com/ accessed online 7/5/2017

Salanova, et al. (2005) "Linking Organizational Resources and Work Engagement to Employee Performance and Customer Loyalty: The Mediation of Service Climate" Journal of Applied Psychology , American Psychological Association 2005, Vol. 90, No. 6, 1217 1227

Schaufeli et al. (2002)." The measurement of engagement and burnout: A two sample confirmatory factor analytic approach". Journal of Happiness Studies, 3, pp. 71-92.
Senaweera, (2008). "Quality Assurance for Financial Services - A Way Forward". Available online at: $<$ http://www.apbsrilanka.org/articales/20_ann/20_pdf_articles/17 L. N Senaweera.pdf).accessed 4/5/2017

Spira, L. and Page, M. (2003). "Risk management: The reinvention of internal control and the changing role of internal audit", Accounting, Auditing \& Accountability Journal, Vol. 16 No. 4 pp. 640 - 661.

Thornton, G. (2009) "Guidance on Monitoring Internal Control Systems, Introduction" The Committee of Sponsoring Organizations of the Treadway Commission (COSO).

Whittington, P. (2001). Principles of Auditing and other Assurance Services. McGraw Hill High Education. 5th Edition.

Williford, K. and Small, D. (2013). "Establishing an Effective Compliance Program: An Overview to Protecting Your Organization". Available online at: http://www.acc.com/

Zinca, C. (2016). "Measuring the value of internal audit in the banking industry" Audit financiar, XIV, Nr. 9(141)/2016, 1009-1024. Avalilable online :http://revista.cafr.ro/temp/Article 9499.pdf. Accessed 8/5/2017 